Editors' introduction to Complicity in Post-1945 Literature: Theory, Politics, Aesthetics, special issue of Comparative Literature Studies. Authors' pre-print version.

\title{
Literature and Complicity: Then and Now
}

Adam Kelly and Will Norman

\section{Historicizing Complicity}

Once one begins to think about complicity, one sees it everywhere. Deriving etymologically from the Latin word complicāre, meaning to fold, complicity shares a root with our modern terms complicate and complex. ${ }^{1}$ If one is complicit, one is folded into a larger system and becomes part of a complex situation. This spatial metaphor might be used in various contexts, to describe the way individuals become part of a society, an environment, or a history. In our modern use of the word, however, complicity conventionally carries with it a negative valence in which individuals are folded into a structure, such as an institution, that causes harm. Often the complicit subject wishes to repudiate aspects of this system, but finds it difficult to do so, or is unwilling to. In such a case, the term complicity takes on a pejorative cast. In Thomas Docherty's recent account, for example, the recognition that the institution one has become folded into is in fact nefarious is the moment when compliance with the rules governing that institution transforms into complicity. ${ }^{2}$ This recognition demands various forms of rethinking: of one's position within the system, of the ethics of one's actions and language, and of one's relationship to others. We begin this special issue, then, with a relation described by a spatial metaphor of folding, with the acknowledgement of harms taking place in the world, and with the necessity for thought.

One reason why complicity seems to be everywhere in our contemporary moment the reason for its apparent ubiquity - is that it must be understood at least in part as a 
correlative to the spread of global capitalism. It has now become almost impossible to engage with the reproduction of human life anywhere on the planet without taking into account the markets that capitalism has multiplied and normalized. If, in Karl Marx's famous claim, capital is to be understood not as a thing but as a social relation between persons, then the analysis of complicity demands that we think apparently individual or isolated ethical problems relationally, through the larger systems that connect persons and groups in the flow of commodities, waste, bodies, information, and finance, and through the markets that fold them continually into new and ever vaster social formations. For Marx in the nineteenth century, as for Vladimir Lenin in the early twentieth, it was still possible to point to substantial areas of the world, including in what we now call the Global North, in which markets were not economically coercive in the sense of offering the only access to the means of subsistence. This is no longer the case. The period since 1945, on which this special issue focuses, is marked by the increasing reach of an economic form of imperialism that has ensured, using violent force where necessary, that human relations are mediated by markets in nearly all spaces, whether geographical or virtual, in ways that are often opaque and difficult to decipher. Complicity, as Devika Sharma's essay in this collection suggests, offers a particularly useful concept with which to articulate and analyse how this process is registered in the experience of those who benefit materially from the uneven distribution of resources that capitalism has sustained.

When faced with the difficulties of identifying and discussing complicity in such nebulous yet pervasive forms, the necessary response is to historicize. Scholars need methods and forms of attention that can do justice to the singularity and intensity of the experience of complicity for situated individuals and groups, while also understanding how those experiences are precipitated by forces that are structural and deeply impersonal. Alongside the evolution of global capitalism and economic imperialism in the twentieth 
century - addressed later in this introduction through consideration of the term neoliberalism - the other indispensible historical context for understanding complicity since 1945 is the emergence of unprecedentedly powerful, authoritarian state regimes, most prominently Nazi Germany, in the immediately preceding era. These were regimes with the capability and will to use new technologies of violence in order to dehumanize and kill large numbers of humans marked as racially other. Such regimes drew upon a longer history of ideologies and practices of racialization, exploitation, dispossession, and annihilation in the service of empire, such as the mass killing of Armenians in the last years of the Ottoman Empire (addressed in this special issue by Pelin Kivrak), the genocide of the Herero and Namaqua under German rule in Southwest Africa between 1904 and 1908, and the atrocities of the Belgian Congo in the late nineteenth and early twentieth centuries. In the longer scale, we must also consider the systematic destruction of indigenous cultures throughout the Americas under European settler-colonialism, and the Atlantic slave-trade from the seventeenth to the nineteenth century, among many other examples.

Consideration of these legacies offers an instructive pre-history of post-1945 complicity. Indeed, some of the earliest mobilizations of the modern concept of complicity, which combine the effects both of the expanding reach of the market for commodities and systematic, state-sanctioned racialization, might be traced to the campaigns in Britain and the United States for the abolition of slavery and the Atlantic slave trade in the hundred years or so after 1750. The historian Thomas Haskell argued in a pair of articles published in 1985 that in these campaigns we can discern the origins of modern humanitarianism, in the newly conceived idea that individuals might be causally involved in a harmful system despite being situated a long distance from those suffering. ${ }^{3}$ In Haskell's controversial account, it was the capitalist market itself that furnished campaigners with what he calls the "perception or cognitive style" necessary to grasp their interfoldedness with the suffering of slaves many 
thousands of miles away. ${ }^{4}$ In a rebuke to class-oriented Marxist accounts of anti-slavery in the period, and in particular to Eric Williams' famous argument that the logic of the abolition of the Atlantic slave-trade should be understood as following from the changing economic interests of British capitalists, Haskell instead placed the market and the discipline it required of its participants at the centre of this key moment in the history of ethics, since it was the market that inculcated a more sophisticated understanding of causation than had previously been possible. ${ }^{5}$ In this account, then, the extension of the market for sugar and other slavegrown commodities both extended the scale of suffering for chattel slaves in the Americas and facilitated the cognitive sophistication necessary for the British bourgeoisie to perceive its complicity in that suffering.

Haskell's foregrounding of distance between individuals and the harms they are implicated in as a key factor in the determination of responsibility encourages us to consider space as such to be the terrain upon which many of the conceptual difficulties of complicity are to be worked through. In one of the landmark interventions in the history of thinking about complicity, Dwight Macdonald claimed in "The Responsibility of Peoples" (1945) that "it is a terrible fact, but it is a fact, that few people have the imagination or the moral sensitivity to get very excited about actions they don't participate in themselves." Macdonald's piece is notable for the way in which it refused to treat the newly discovered horrors of the Nazi death camps in isolation from longer histories of colonialism and stateauthorized racial violence. Macdonald saw 1945 as a moment at which a new, more globally conscious chapter in the history of morality might be opened up, in a way we could compare to the shift identified by Haskell in the abolitionist cultures of the late-eighteenth and earlynineteenth centuries. Thus Macdonald saw the attempted genocide of indigenous peoples in Australia, the British enabling of mass famine in colonial India, the excessive violence of the Boxer Rebellion's suppression in China, and the Jim Crow laws of the Southern United 
States as all posing a challenge to citizens of the Allied powers: how can one develop the imaginative capacity necessary to overcome the vast distances separating individuals from the harms they are nevertheless folded into?

In the US context, there are reverse echoes here of Ralph Waldo Emerson's exhortation, in his famous essay "Self-Reliance," for the Northern abolitionist to focus his attention on those family members closest to him, "and never varnish your hard, uncharitable ambition with this incredible tenderness for black folk a thousand miles off."7 Repeatedly in the long history of thinking about complicity, the physical and relative location of embodied selves, often considered alongside racial phenotypes, emerges as a determining factor in shaping the affective forms and imaginative limits of human interfoldedness. It is in those instances where bodies are found to share an ambient space that complicity is more easily recognized. In the current special issue, several contributors discuss such moments: in Devika Sharma's essay the realization that Scandinavian tourists bathing in the Mediterranean sea are sharing the water with migrants attempting to cross into Europe from North Africa; in Will Norman's, the acknowledgement of Mary McCarthy's liberal narrator that she has willingly placed herself within the same claustrophobic and erotically charged atmosphere as an antiSemitic colonel; and in Jessica Hurley's, the emergence of a common transpacific nuclear space suffused with radiation. Conversely, as Jessica Copley's essay shows, the trope of sequestration, in which individuals are sealed off in locations proximate to but separate from society, serves to foreground and dramatize the spatial tensions inherent in complicit relationships.

\section{Complicity Studies Then and Now}


1945 and the discovery of the death camps, then, provides us not with an origin point for modern concepts of complicity, as is sometimes tacitly or explicitly assumed, but rather with a milestone in its longer history, at which persistent questions about individual responsibility and guilt in relation to large-scale racist and colonial practices were rearticulated in new forms and contexts. Macdonald recognized that in spite of this longer history and its uses for understanding the present, the mass extermination of Jews in Europe under Nazi occupation presented some unprecedented characteristics. Particularly confounding was the sense in which, as he put it, Auschwitz represented "an end in itself," thus appearing to query familiar arguments - by Marx and others - that attributed large-scale atrocities to the instrumentalizing logic of capitalism. ${ }^{8}$ Also significant and unprecedented was the active encouragement and inculcation by the Nazi regime of a sense of complicity for these atrocities among German citizens. The goal was to establish a new principle of exculpation in readiness for Allied efforts to administer legal justice: "if everyone is guilty, no one is guilty" (a subject addressed by Kai Evers's essay here). ${ }^{9}$ As Macdonald acknowledges in his essay, this last insight he owed to his friend, the German émigré intellectual Hannah Arendt, identified by Naomi Mandel in her essay for this issue as representing one of two principal strands of thought and scholarship about modern complicity (the other being Theodor W. Adorno). Both Arendt and Adorno emerged from their philosophical training in the German tradition during the interwar period and emigrated to the United States in flight from National Socialism. In their personal and historical experiences of anti-Semitism, transatlantic exile, and Holocaust survival, they found resources for largescale renegotiations and reassessments of Kantian and Hegelian thought respectively. These interventions have impacted the theorization of complicity right up to the present day.

In the case of Arendt, her interrogations of Holocaust guilt and responsibility led her to explore the ways that totalitarianism undermined the Kantian philosophical foundations for 
considerations of ethics and judgment. As she put it in 1954, "for those engaged in the quest for meaning and understanding, what is frightening in the rise of totalitarianism is not that it is something new, but that it has brought to light the ruin of our categories of thought and standards of judgment." ${ }^{\prime 10}$ In Adorno's dialectical work, the Hegelian Geist is discovered to be irrevocably compromised and polluted by the existence of the death camps. Auschwitz, he claimed, "irrefutably demonstrated the failure of culture":

By restoring itself after what transpired in its landscape without resistance, it has turned entirely into that ideology which it potentially was, ever since it took it upon itself, in opposition to material existence, to breathe life into this latter with the light, which the separation of the Mind from manual labor withheld from such. Whoever pleads for the preservation of a radically culpable and shabby culture turns into its accomplice ... ${ }^{11}$

This important passage from Negative Dialectics (1966) expresses one of Adorno's key contentions for the study of complicity in relation to literature: that the very separation of a rarefied and autonomous realm of culture from the world of materiality and labour was false from the beginning, masking a deep unacknowledged complicity between the two (for a contemporary iteration of this argument, see Norwegian poet Cathrine Grøndahl's "The Price of a Poem," discussed here by Devika Sharma). It is striking that both Arendt and Adorno conceive of the Holocaust not as causing crises in the history of thought, but rather as being the event that makes such crises visible, by revealing the faultlines and unresolved structural contradictions that had long since been concealed within the philosophical and cultural edifice. In this sense, to historicize complicity is to trace the moments at which the concept itself, which so frequently evades attention by passing as convention, is wrested to the surface and subjected to scrutiny, demanding fundamental re-evaluations of our very modes of beingtogether, and of thinking. 
The immediate postwar period, we contend, represents one such moment. Our present is another. The first two decades of the twenty-first century have produced a steadily increasing body of work from different disciplines dealing with questions of complicity. From the tradition of legal philosophy, Christopher Kutz made an important intervention in Complicity: Ethics and Law of the Collective Age (2000), arguing that the individualistic Kantian and consequentialist theories of accountability that had long dominated moral philosophy were simply unequipped to cope with the exigencies imposed by an era characterized by increasingly mediated and complex relationships among individuals, collectivities, and harms. Kutz's approach featured several distinctive characteristics which have become pervasive among scholars of complicity, but perhaps the most important is his insistence that "the hidden promise of complicity is the conception of community upon which it draws: a world where individuals shape their lives with others, in love mixed with resentment, and in cooperation mixed with discord." 12 Versions of this claim to the potential reversibility of complicity's conventionally negative valence form a connective thread joining several subsequent accounts of complicity, including two influential studies from the 2000 s, Mark Sanders' Complicities: The Intellectual and Apartheid (2002) and Naomi Mandel's Against the Unspeakable: Complicity, the Holocaust and Slavery in America (2006). In Alexis Shotwell's more recent account, complicity offers a possible antidote to "purism," the pernicious notion that states of innocence and purity are both desirable and recoverable. ${ }^{13} \mathrm{In}$ Debarati Sanyal's analysis, "complicity and solidarity may be two sides of the same coin," though she also concedes that the awareness of complicity can also "foster resignation and disavowal."14

One genealogy for the latently positive potential of complicity can be found in Mark Sanders' reading of Jacques Derrida's writing on Martin Heidegger and National Socialism. ${ }^{15}$ In Sanders' account, complicity becomes a deconstructive motif in which the intellectual 
becomes "a figure of responsibility-in-complicity" and complicity names "the basic foldedtogether-ness of being, of human being, of self and other. Such foldedness is the condition of possibility of all particular affiliations, loyalties, and commitments." ${ }^{, 16}$ Such a poststructuralist approach exemplifies, it must be said, a very different kind of dialectics to that practiced by Adorno in his writings about complicity, where to make any accommodations with the violence of the world is to share in its madness. His Minima Moralia: Fragments from Damaged Life (1951) concludes with the assertion that "the only philosophy that can reasonably be practiced in the face of despair is the attempt to contemplate all things as they would present themselves from the standpoint of redemption. Knowledge has no light but that shed on the world by redemption: all else is reconstruction, mere technique." ${ }^{17}$ This characteristically Adornian position offers a warning to those who would claim complicity as an effective position from which to engage the world politically. From the perspective of his work, there is a grave danger that arguments that take as their starting point a complicit rejection of purity are already setting themselves up for an acceptance of the way things are. ${ }^{18}$

The essays included in our special issue articulate a variety of positions with regard to this persistent question in twenty-first-century complicity scholarship, concerning the recognition of complicity as grounds for political engagement and action. While Naomi Mandel, Jessica Hurley, and Pelin Kivrak directly take up arguments for complicity's potentially positive valence in both theory and fiction, other essays by Will Norman, Devika Sharma, and Kai Evers are more ambivalent, choosing to emphasize representations in which complicity generates states of deception and confusion, stupefaction and stagnation. In such cases of cognitive impasse, the task of the writer with regard to complicity emerges as one of unsettling, or as Mary McCarthy puts it, "embarrass[ing] the reader and, if possible, myself too."19 This approach aims to prevent states of complicity from becoming comfortable, even 
cosy, ones in which to dwell. Literary strategies of formally estranging experiment, as in the cases of Annie Ernaux (in Gabriella Lindsay's essay) and Arno Schmidt (Evers), deployment of uncanny doubling tropes in McCarthy and Vladimir Nabokov (Norman), and conjuring of awkward disruptive moods in Viktor Højrup (Sharma) and again Ernaux (Lindsay), have the effect of bringing to consciousness those affiliations that link selves to objects they either wish to repudiate or refuse to acknowledge.

\section{Complicity, the Literary and the Aesthetic}

It is notable that many of the major advances in midcentury thinking about complicity came from figures like Arendt, Adorno, and Jean-Paul Sartre (the latter discussed in this issue by Jessica Copley), who rejected the academic disciplinary boundaries and specializations of their day, preferring rather to roam between and among sociology, philosophy, political science, history, and literature. It is perhaps for this reason that the literary has never been far from considerations of complicity, even if it has rarely occupied the centre stage. While the literary interests of Adorno and Sartre are evident enough in their work, the same is not so immediately apparent in Arendt's. However, in the course she taught at the University of Chicago, "Political Experience in the Twentieth Century," she set very little reading from political science, asking her students instead to immerse themselves in literary testimonies, memoirs, and essays: poems by Berthold Brecht, fiction by William Faulkner, and Hanna Hafkesbrink's Unknown Germany. ${ }^{20}$ She set them extracts from Proust's A la recherche in order to discover the specific forms of anti-Semitism in fin-de-siècle France, and Conrad's Heart of Darkness for insights into the unstable relations between civilization and barbarism. "Imagination is the pre-requisite for understanding," she wrote in her 1955 course notes. 
"You," the students, "should imagine how the world looks from the different points of view where these people are located." 21

Arendt's deep pedagogical investment in the power of literary representation as a pathway to the understanding of situated social experience finds its echoes in Dwight Macdonald's insistence on imagination as the key to forging new forms of global responsibility in "The Responsibility of Peoples." Macdonald makes numerous literary allusions in his essay, including another to that urtext for the aesthetics of complicity in the twentieth century, Heart of Darkness. From the perspective of a Kantian view on the imagination, which was clearly influential on Arendt and Macdonald, their work suggests that a subject's recognition of her or his own complicity comes through an act of intuition or representation. Understanding our own complicit relationships, then, would require of us imaginative work capable of bridging the gap between the world of concrete personal experience and that which, whether because of distance or because of its abstract nature, remains unavailable to the senses. Seen in this way, the literary offers both a rich archive of experience for the imagination to work upon and a means of modelling the kind of imaginative processes that might allow us to grasp and conceptualize states of complicity.

If Arendt wanted her students to use literature as a means to experiment imaginatively by occupying subject positions in different locations, then Kutz's more recent work on complicity also stresses the importance of the "positionality and relationality of accountability" in the collective age. ${ }^{22}$ Works of literature, he suggests, offer productive methods for mapping and articulating the irreducible particularity of these socially embedded relations, in which, for example in his reading of Herman Melville's Billy Budd, a single individual might respond to a harmful system in multiple and conflicting ways, determined by their occupation of several social roles and positions simultaneously. It is what Kutz calls the "refractory" nature of literature, its intractable commitment to social complexity and 
resistance to reductive interpretation, that makes the process of literary criticism, in his account, comparable to that of making ethical and legal judgements on tangled and thorny cases of accountability. ${ }^{23}$ From the perspective of a literary scholar, it is clear enough that his claims here rest on a view of the literary orientated towards the novel, and especially towards its nineteenth-century guises (his examples are drawn from Melville, Fyodor Dostoevsky and Nathaniel Hawthorne). Nevertheless, they serve as a prompt for us to press on the question of what distinctive insights literary studies might offer for the study of complicity.

The parallel between aesthetic judgements and moral ones has a long philosophical history, much of which refers back to Kant's Critique of Judgement. According to Kant it is above all the role and value of disinterestedness in the forming of judgements that links the two. One of complicity's implications, however, is precisely to call into question the possibility of disinterestedness in the forming of such judgements. In 1857, Charles Baudelaire articulated this knowledge when he had the seductive but dissolute voice of his poem "Au Lecteur" ("To the Reader") solicit the reader as "- -Hypocrite lecteur, - mon semblable, — mon frère!” (“- - Hypocrite reader, —fellowman, — my twin!”), crystallizing a tradition of writing that knowingly transformed the reader into an accomplice. ${ }^{24}$ Baudelaire's inspiration for this literary strategy likely came from the doppelgänger tales of Edgar Allan Poe, whom he translated and praised on several occasions, and its influence can be felt pervasively across the literature of decadence in the late nineteenth and early twentieth centuries. The dominant feature of this strategy is a deployment of voice and style in which the reader is drawn and enfolded into ethically compromised situations through modes of confession, flirtation, eroticism, flattery, and appeals to shared taste. This tradition of tainted intimacy between reader and writer offers just one example among many of an aesthetic strategy developed in response to notions of complicity, but it is instructive because it so explicitly models the ways in which complicity undermines the operation of Kantian 
aesthetics by removing disinterestedness from the range of available readerly dispositions. In the work of post-1945 writers who draw on this tradition, such as Nabokov, Ernaux, and Schmidt, all discussed in this issue, states of complicity are not simply represented; they are also enacted in the process of being formed and dissolved through collaboration. As Humbert Humbert proclaims to the reader of Nabokov's Lolita, perhaps the most direct inheritor of this tradition, "Imagine me; I shall not exist if you do not imagine me."25

An aesthetics of complicity, then, must begin with the perceiving subject already positioned within the ambit of entanglement with the aesthetic object, and this is the position from which our special issue proceeds. While several significant interventions on the topic of complicity have been made by literary scholars, often working in predominately theoretical modes, we wish to explore the variety of ways in which ideas of complicity shaped literary history as it has developed since the mid-twentieth century, and in the process became available to thought in new and distinctive ways. In other words, our contention is not only that fiction, drama, and poetry have reflected debates going on in the disciplines of political science, philosophy, and the law, but that they have also offered their own methods of cognizing complicity by drawing on the discursive and formal qualities particular to literary writing in this period. In recovering, comparing and evaluating these methods, we stand to see complicity again, but with fresh eyes.

\section{Bolaño, the Holocaust, and the Contemporary World System}

While this special issue addresses a wide range of literary texts that have given form to the problem of complicity at various moments of its post-1945 and contemporary development,

we have organized the essays in pairs. The issue begins with essays by Naomi Mandel and Devika Sharma, which address complicity in the twenty-first century. These focus, 
respectively, on the implications of digital media for complicity studies and on Scandinavian "hypocrisy fiction" and the contemporary predicament of privilege. The second pair travels back to the mid-twentieth-century United States and its emergence as a global superpower. Will Norman's essay examines the aesthetics of complicity with anti-Semitism in relation to midcentury liberalism, while Jessica Hurley's discussion of the 2011 Fukushima Daiichi nuclear disaster and Ruth Ozeki's 2013 novel $A$ Tale for the Time Being traces the shifting modes of nuclear entanglement across the North Pacific back to the Atoms for Peace programme through which the US brought nuclear power to Japan. The third pair retains a focus on World War Two and its aftermath for the warring powers, through their interest in particular bounded spatial forms: the barrack, the camp, and the prison. Jessica Copley compares the trope of sequestration in post-war work by Jean-Paul Sartre in France and Hiroshi Noma in Japan. Gabriella Lindsay, meanwhile, reads Annie Ernaux's deployment of the camp as a figure used to articulate shared territory between Vichyist collaboration, French colonialism in North Africa, and holiday camps for adolescents in the 1960s. The final pair of essays returns to the German context, and the question of complicity with Nazism. Kai Evers analyses Arno Schmidt's attempts in his postwar fiction to articulate a paradoxical state of "complicit non-complicity" with National Socialism, while Pelin Kivrak discusses the ways in which more recent Turkish-German representations of complicity connect the post-1989 cosmopolitan moment back to the Holocaust and other mass killings, specifically the Armenian Genocide.

Our geographical case studies - the United States, Japan, France, Germany, and Scandinavia - make clear that we are most concerned with nations that were profoundly affected by the events and aftermath of World War Two. However, these nations unquestionably also form part of the Global North. In this regard they the offer particular, situated perspectives from which new discourses of complicity emerged, based primarily on 
the acknowledgement of relative economic advantage. As the editors of a recent volume on the topic write, "It may be that some of the most damaging structural forms of complicity arise from one's being geopolitically positioned on the privileged side of various international and global hierarchies, in the sense that such citizens are likely to be complicit in the reproduction of hierarchies that generate enormous suffering. ${ }^{26}$ In the present introduction, then, we would like to redress the balance somewhat by examining a work that emerges from, and engages with, the periphery (or semiperiphery) of the world system. ${ }^{27}$ The Chilean writer Roberto Bolaño's 892-page novel 2666 has been far from peripheral to debates in literary studies, with its status as perhaps the most critically lauded novel of the twenty-first century solidifying yearon-year since its original publication in Spanish in 2004 and English translation in 2008. While set primarily in Mexico, it is a text that enables an engagement with complicity on the geographical scale of the capitalist world system. As one critic puts it, "The novel's form is systematically world-historical, uniting a particular semiperiphery (Ciudad Juárez) and a particular historical conjuncture (late capitalism at the millennium) with a vast geopolitical scope. $" 28$

Beginning as a kind of campus satire that exposes the lamentable lack of political awareness among a privileged set of European literary critics during the 1990s, 2666 follows them to Mexico as they search for their enigmatic favourite writer, Benno von Archimboldi. After three sections which, through a series of often surreal and digressive passages, hint at certain dark realities lying at the fringes of the stories being told, the novel pivots around its notorious fourth section, "The Part About the Crimes." The crimes in question are the unsolved murders of as many as 5,000 female maquiladora workers along the US-Mexican border. This real-life event is immortalised by Bolaño through more than 300 pages of hardboiled description of the bodies of these women in the state they were found, interspersed with accounts of failed attempts by various detective figures to solve the crimes. Without offering 
an explicitly Marxist analysis of the situation, Bolaño guides his reader to the insight that these deaths are systemic in character, since the women provide a surplus population whose supply of labour is barely diminished by the regular indiscriminate deaths of particular workers. Indeed, the maquiladora murders might even be interpreted as a means to keep labour in line, isolating the women from collective action and preventing the formation of the kind of factoryfloor proletarian consciousness imagined in The Communist Manifesto. Throughout the section and the novel, Bolaño combines a materialist lens with a gendered one, uncovering the deeply misogynistic forces that intertwine with capitalist class relations in the region and elsewhere. Certainly, the male elite in Mexico are not suffering, since "the economic situation along their strip of border was good and still improving," as we are informed in a parenthetical aside late in the section. ${ }^{29}$

At the formal level, as Sharae Deckard notes, 2666 rejects the aesthetics of magical realism long associated with the Latin American "Boom" that began with Gabriel Garcia Márquez's 1967 novel One Hundred Years of Solitude. ${ }^{30}$ Through its easy commodification in the global literary marketplace, this literature had become complicit, in Bolaño's stated view, with the maintenance of dictatorial regimes and neoliberal inequalities in the region. ${ }^{31}$ In place of magical realism, 2666 gives us a "critical irrealism" that sees vampires, ghosts, mummies, and zombies appear in the novel only as metaphors or images in dreams, never in reality. ${ }^{32} \mathrm{We}$ would add that this rejection of magical realism might equally be seen as a rejection of the magical thinking of neoliberal capitalism, where the market as "superior information processor" is imagined as meeting all consumer preferences without externality. ${ }^{33}$ In Bolaño’s novel, the maquiladora murders represent a repressed and grievous externality, one that exposes the gruesome truth at the heart of the global market system. Starting with the critics who refuse to read literature for its political meaning, 2666 explores the multiple ways that citizens of neoliberal societies have become complicit in the violence that underpins 
contemporary market relations, distracting themselves in various ways from the brutal realities of millennial capitalism. "No one pays attention to these killings," a minor character observes at one point, "but the secret of the world is hidden in them" (348).

In the final section of 2666, "The Part About Archimboldi," Bolaño takes the reader back from millennial Mexico to the Germany of World War II. The protagonist of the section, Hans Reiter (later to become the writer Archimboldi) is a soldier in the Wehrmacht, whose strangely ethereal existence and nature ("He seemed less like a child than a strand of seaweed") has seen him float through the war while managing not to kill a single enemy soldier (639). That is until he meets Leo Sammer, who tells Reiter how his low-level bureaucratic existence as the Nazi overseer of a Polish town was disrupted when he was sent, in error, "a trainload of Greek Jews" bound for Auschwitz (752). Their presence in the town proves an anxious distraction from Sammer's daily business until he is told to "dispose of them" (759), which he eventually does through establishing an ad hoc and amateur firing squad outside the town. “Anyone else in my place [...] would have killed all those Jews with his own hands. I didn't. It's not in my nature," Sammer protests to Reiter. "I was a fair administrator. I did good things, guided by my instincts, and bad things, driven by the vicissitudes of war" (767). One night Sammer is found strangled, and the reader is given to understand that Reiter is the culprit.

In her essay for this special issue, Naomi Mandel remarks on the centrality of the Holocaust - with its distinctive combination of epistemic truth and moral clarity - to the emergence and development of modern thought on complicity. By offering a thinly veiled variation on perhaps the twentieth century's most notorious case of Holocaust complicity, that of the Nazi bureaucrat Adolf Eichmann, Bolaño invokes the standard narratives of complicity that have emerged from a reading of the twentieth century that places the Holocaust at its centre. But in bringing this familiar image of complicity into the same frame as the Mexican maquiladora murders of the end of the century, Bolaño is asking us to replace a vision of 
complicity as politically, morally, and temporally bounded with one that is more diffuse and difficult to narrate or pin down. If the central fact of the old complicity was the Shoah, 2666 seems to be saying, then the central fact of the new complicity is the Mexican femicides. To understand the former, we require a vision of "organised guilt and universal responsibility," in Arendt's words. ${ }^{34}$ To understand the latter, to confront its ongoing nature in the world in which we still live, a new vision of disorganised guilt and systemic responsibility is required.

\section{Neoliberalism, Complicity, and Class}

As we have already intimated, one prominent name for the mode of contemporary capitalism that necessitates this new vision of disorganised guilt and systemic responsibility is neoliberalism. As a huge number of scholars across a diverse range of disciplines and fields have by now established, the period from 1945 to the early twenty-first century has been characterised by the rise to power of the intellectual movement, political formation, and economic regime signalled by this term. Scholarship on neoliberalism - which has been far more abundant than scholarship on complicity, and has not until now intersected with it - is by no means unified in its methods and arguments. Indeed, the various ways in which the term has been made to signify has become somewhat notorious. This scholarship can nevertheless be broadly divided into three camps: those who consider the intellectual history of the neoliberal turn; those who privilege its economic and material origins; and those who emphasise its effects on modes of subjectivity. For those in the first camp, the key event is usually the formation of the Mont Pèlerin Society (MPS), established by Friedrich Hayek in 1947 in order to argue the cause of liberal capitalism against the burgeoning socialist and social democratic trends of the postwar era. Scholars have positioned the MPS at the heart of a "Neoliberal Thought Collective," which developed outposts in academia, think thanks, and other non-governmental 
organisations in the post-1945 era. ${ }^{35}$ This collective eventually found its recommendations followed in Pinochet's Chile in 1973, in the UK and US towards the end of the 1970s, and in many other countries in the Global South and Eastern Europe across the next two decades. ${ }^{36}$ For scholars in the second camp who emphasise an economic and materialist approach, all of these latter milestones in neoliberalism's rise to power should be seen as the effects of a more fundamental shift: the slowdown in capitalist profitability in the early 1970 s, and the resulting turn from production to financialization in the Global North alongside new forms of accumulation and expropriation in the Global South. ${ }^{37}$

We have made clear that we see complicity as inseparable from developments in the capitalist world system over the modern period. Both of the accounts described above deriving from intellectual history and Marxist crisis theory respectively - have something to add to this discussion, not least in how they supplement an historical approach that positions the Holocaust as twentieth-century complicity's defining event (an approach that can, as Jessica Copley's essay argues, be made to serve ideological ends in the dominant historiography of the post-1945 period). But the interest for complicity studies of the scholarship on neoliberalism lies most of all in the claims that have been made for the emergence of a distinctive form of contemporary subjectivity shaped by living in societies that have undergone processes of neoliberalization. Michel Foucault is the originating figure in this lineage, with his 1979 lectures on biopolitics having laid the ground for an approach to neoliberal subjectivity as a form of entrepreneurial relation to one's own stock of human capital. ${ }^{38}$ Developing Foucault, Wendy Brown describes neoliberalism as "an order of economic reason that, when it becomes ascendant, takes shape as a governing rationality extending a specific formulation of economic values, practices, and metrics to every dimension of human life." 39 Subjectivity becomes economic in orientation, while the economy becomes subjective. "The neoliberal economy is 
a subjective economy," writes Mauricio Lazzarato; in such an economy, the subject cannot help but become "at once responsible and guilty for his particular fate." 40

These writers on neoliberal subjectivity describe a novel state of affairs that challenges the assumptions of unencumbered agency and free will upon which much modern thought about ethics and responsibility depends. A series of questions arise in response to the portrait this scholarship offers of the contemporary dispensation. Is it possible, in a neoliberal age, to be anything other than a neoliberal subject? And if, as we have suggested, neoliberal capitalism is underpinned by brutal violence, is the neoliberal subject then unavoidably complicit in this violence, with no means of resisting it? Furthermore, if under neoliberalism the centrality of human capital theory means that, as Brown puts it, "labor disappears as a category, as does its collective form, class, taking with it the analytic basis for alienation, exploitation, and association among laborers," then are the maquiladora workers depicted in 2666 to be understood as entrepreneurs of the self and wielders of human capital, and therefore as complicit in perpetuating the system that causes them to suffer and die $?^{41}$ Can complicity persist as a useful analytical category without the possibility of resistance to complicity?

As Annie McClanahan points out in a sharp recent critique of the foremost scholarship on neoliberal subjectivity, much of this scholarship is not only Foucauldian but neo-Gramscian in orientation, emphasising terms such as "common sense," "consent," and "hegemony" as a means to explain how neoliberal ideas have (supposedly) come to dominate everyday life. These Gramscian terms all have a close relationship to notions of complicity, since they involve the subject's alignment with discourses and practices of power. McClanahan queries whether such discourses can be causes as well as effects of historical transitions, and she argues that the neo-Gramscian emphasis on consent disguises the reliance of neoliberal policy on force. Most pertinently for our purposes, she questions the implied universality of neoliberal "common sense" and highlights the absence in this scholarship of "entirely different and more radical 
forms of consciousness." ${ }^{, 42}$ Put into the terms of this introduction, her approach frames the following question: if the recognition of class relations is a key moment in thinking complicity, then how can such recognition be mobilised as a means of resisting complicity? This is where the changing constitution of class relations becomes crucial. McClanahan argues that the worldview that underpins claims of a near-universal mode of neoliberal subjectivity is the worldview of a declining professional managerial class. What we are seeing, she claims, is "the introduction of economic exigencies into the lives of people once shielded from them." Against the (still-privileged) lives of such subjects, we need to consider the huge and increasing numbers of people who lack a college degree, are underemployed in the gig economy or a lowwage service job, are substantially indebted, and rent rather than own their homes. These are subjects "unlikely to see any of this precarity as an interest-bearing investment in [their] future," as the scholarship on neoliberalism insists they must; nor are these subjects necessarily complicit in what Mirowksi calls the neoliberal "theater of cruelty" through interpellation by the brand of popular culture - TV survival games, violent computer games - that Jane Elliott dubs "the microeconomic mode." $"$ As tempting as it is to see capitalist culture as determining of subjectivity in this way, McClanahan emphasises instead the responsivity of subjects to the actual (rather than imagined) economic exigencies underpinning their lives.

This is where a grim diagnosis begins to shift, dialectically, into a reason to hope. It may be that the class of subjects who benefit materially from complicity with capitalist exploitation is shrinking in size, relative to the class of subjects who fail to benefit. Moreover, if it is also the case that "growing portions of the population of the developing and developed world are finding themselves not 'entrepreneurs of the self' but no longer worth capital's investment at all," then these "absolutely redundant" populations, excluded even from the process of wage-labour exploitation, have no reason to act in a way complicit with capitalism's hold on everyday life and social reproduction. ${ }^{45}$ McClanahan thus ends her article by pointing 
to the promise of an emerging counterconsciousness that instantiates what Gramsci termed "good sense" (the oft-overlooked opposing term in his dialectic). This counterconsciousness, driven by necessity to seek a realm of freedom beyond capitalism, will come to challenge the neoliberal "common sense" that "can only produce complicity and compliance."46

To what extent post-neoliberal "good sense" will take the forms of action associated with what we have learned over recent years to call "populism" is an open question. Many Marxist and post-Marxist critics have begun to argue that the now-regnant populism of the right can be challenged only by a resurgent populism of the left. ${ }^{47}$ In these accounts, there is no longer value in returning to the former political centre-ground, the liberal space which our special issue implies has been the most fertile ground for, and can be helpfully analysed through, the notion of complicity. Indeed, one of the key arguments made cumulatively by the essays in this issue is that complicity since 1945 can profitably be understood as naming the structure of feeling that corresponds to postwar liberalism, and to the most intransigent contradictions of its regime. If we understand the economic and class relations that underpinned the era's cultural production and moral sensibility to be undergoing a major new realignment, then our thinking about complicity will need to change too. Is it still the case, then - as scholars of complicity have argued, and as many of the authors below suggest - that recognising complicity is the condition of possibility for positive action? Or does the true harbinger of the future lie in the kind of revolutionary consciousness structurally removed from complicity with the capitalist system? These questions, inextricable from an analysis of the class relations currently shifting under our feet, we offer to the field of complicity studies. One thing of which we are confident is that literature - read for its dialectical rendering of the contradictions of its present - can help to offer us the answers. 
${ }^{1}$ On complicity's etymology, see Mark Sanders, Complicities: The Intellectual and Apartheid (Durham, NC: Duke University Press, 2001), 5.

${ }^{2}$ Thomas Docherty, Complicity: Criticism between Collaboration and Commitment (London: Rowman and Littlefield, 2016), 10.

${ }^{3}$ Thomas Haskell, "Capitalism and the Origins of Humanitarian Sentiment," pts. 1 and 2, American Historical Review 20, no. 2 (1985): 339-361; 20, no. 3: 547-566.

${ }^{4}$ Haskell, “Capitalism,” pt. 1: 342.

${ }^{5}$ See Eric Williams, Capitalism and Slavery (Chapel Hill: University of North Carolina Press, 1944).

${ }^{6}$ Dwight Macdonald, “The Responsibility of Peoples," in The Responsibility of Peoples and Other Essays in Political Criticism (Westport, CT: Greenwood Press, 1957), 39.

${ }^{7}$ Ralph Waldo Emerson, “Self-Reliance," in Essays and Lectures (New York: Library of America, 1983), 262.

${ }^{8}$ Macdonald, "Responsibility of Peoples," 17.

${ }^{9}$ Ibid., 34.

${ }^{10}$ Hannah Arendt, "Understanding and Politics," Partisan Review, vol. 20, no. 4 (1954): 388.

${ }^{11}$ Theodor W. Adorno, Negative Dialectics, trans. Dennis Redmond (Frankfurt am Main: Suhrkamp Verlag, 2001), 360.

${ }^{12}$ Kutz, Complicity, 259.

${ }^{13}$ Alexis Shotwell Against Purity: Living Ethically in Compromised Times (Minneapolis: University of Minnesota Press, 2016).

${ }^{14}$ Debarati Sanyal, Memory and Complicity: Migrations of Holocaust Remembrance (New York: Fordham University Press, 2015), 1, 2. 
${ }^{15}$ The case of Heidegger's accommodations with National Socialism has of course received much attention, particularly since the publication of his Black Notebooks in 2014 reaffirmed to an even greater extent the centrality of anti-Semitism to his philosophical thought. See, for example, Heidegger's Black Notebooks: Responses to Anti-Semitism, ed. Andrew J. Mitchell and Peter Trawny (New York: Columbia University Press, 2017).

${ }^{16}$ Sanders, Complicities, 11.

${ }^{17}$ Theodor W. Adorno, Minima Moralia: Reflections from Damaged Life, trans. E. F. N. Jephcott (London: Verso, 2005), 247.

${ }^{18}$ For a recent critique of the importance Adorno grants to "the standpoint of redemption," see Martin Hägglund, This Life: Secular Faith and Spiritual Freedom (New York: Pantheon, 2019), 324-29.

${ }^{19}$ Mary McCarthy, "Settling the Colonel's Hash," in On the Contrary (London: Heinemann, 1962), 226.

${ }^{20}$ Information on Arendt's course, including the quotation from her teaching notebooks, is reported in Wolfgang Heuer, "Verstehen als Sichtbarmachen von Erfahrungen: Die Brücke zwischen Denken und Urteilen," in Dichterisch denken: Hannah Arendt und die Künste, ed. Wolfgang Heuer and Irmela von der Lühe (Göttingen: Wallstein Verlag, 2007), 243-57. English translation available at http://www.wolfgang-heuer.com/wpcontent/uploads/heuer_wolfgang_imagination_bari.pdf.

${ }^{21}$ For a more detailed account of the importance of literature for Arendt's thought, see Richard H. King, "Hannah Arendt and the Uses of Literature," Raritan 36, no. 4 (2017): 10624.

${ }^{22}$ Kutz, Complicity, 255.

${ }^{23}$ Ibid., 13. 
${ }^{24}$ Charles Baudelaire, The Flowers of Evil, trans. James McGowan (Oxford: Oxford World's Classics, 1998), 7.

${ }^{25}$ Vladimir Nabokov, Lolita (New York: Putnam, 1958): 131.

26 Afxentis Afxentiou, Robin Dunford and Michael Neu, "Introducing Complicity," in Exploring Complicity: Concept, Cases and Critique, ed. Afxentiou, Dunford, and Neu (London: Rowman \& Littfield, 2016), 13n14.

27 This language of core, periphery, semiperiphery, and world system is drawn from the theoretical terrain of literary world-systems analysis, as exemplified for instance in the Warwick Research Collective's Combined and Uneven Development: Towards a New Theory of World Literature (Liverpool: Liverpool University Press, 2015).

${ }^{28}$ Sharae Deckard, "Peripheral Realism, Millennial Capitalism, and Roberto Bolaño's 2666," Modern Language Quarterly 73, no. 3 (2012): 353.

${ }^{29}$ Roberto Bolaño, 2666, trans. Natasha Wimmer (London: Picador, 2008), 593. Further references in parentheses.

${ }^{30}$ Deckard, "Peripheral Realism," 353.

${ }^{31}$ In a 2002 email to fellow writer Horacio Castellanos Moya, Bolaño decried "the rancid private club full of cobwebs presided over by Vargas Llosa, García Márquez, Fuentes, and other pterodactyls." Moya, "Bolaño, Inc.” Guernica (1 November 2009). https://www.guernicamag.com/bolano_inc/

32 Deckard, "Peripheral Realism," 355.

${ }^{33}$ Philip Mirowski, "Hell is Truth Seen Too Late," boundary 2 46, no. 1 (2019): 15.

${ }^{34}$ See Hannah Arendt, "Organized Guilt and Universal Responsibility,” in Essays in Understanding, ed. Jerome Kohn (New York: Harcourt, Brace, 1994): 121-32.

${ }^{35}$ The term "Neoliberal Thought Collective" derives from The Road from Mont Pèlerin, ed. Philip Mirowski and Dieter Plehwe (Cambridge, MA: Harvard University Press, 2009). For 
intellectual histories of neoliberalism that emphasise the importance of Hayek and the Mont Pèlerin Society, see Angus Burgin, The Great Persuasion: Reinventing Free Markets since the Depression (Cambridge, MA: Harvard University Press, 2012); Daniel Steadman Jones, Masters of the Universe: Hayek, Friedman and the Birth of Neoliberal Politics (Princeton, NJ: Princeton University Press, 2012).

${ }^{36}$ For a powerful account of neoliberalism's historical response to crisis, see Naomi Klein, The Shock Doctrine: The Rise of Disaster Capitalism (London: Allen Lane, 2007).

${ }^{37}$ The most influential versions of the materialist argument are David Harvey, A Brief History of Neoliberalism (Oxford: Oxford University Press, 2005); Robert Brenner, The Economics of Global Turbulence (London: Verso, 2006).

${ }^{38}$ See Michel Foucault, The Birth of Biopolitics: Lectures at the Collège de France, 1978-79. Ed. Michel Senellart, Trans. Graham Burchell (Basingstoke: Palgrave, 2008).

${ }^{39}$ Wendy Brown. Undoing the Demos: Neoliberalism's Stealth Revolution (New York: Zone Books, 2015), 30.

${ }^{40}$ Maurizio Lazzarato. The Making of the Indebted Man: An Essay on the Neoliberal Condition. Trans. Joshua David Jordan (London: MIT Press, 2012), 38, 9.

${ }^{41}$ Brown, Undoing the Demos, 38. See also Mirowski's claim that "human capital obliterates labor" and that "once a neoliberal worldview takes hold, it ruthlessly empties all Marxist categories of their cogency, and it literally becomes impossible to think like a Marxist." "Hell is Truth," $14,13$.

${ }^{42}$ Annie McClanahan, "Serious Crises: Rethinking the Neoliberal Subject," boundary 246.1 (2019): 111.

43 Ibid., 118.

${ }^{44}$ Ibid., 119; Philip Mirowski, Never Let a Serious Crisis Go to Waste: How Neoliberalism Survived the Financial Meltdown (London: Verso), 133; Jane Elliott, The Microeconomic 
Mode: Political Subjectivity in Contemporary Popular Aesthetics (New York: Columbia University Press, 2018).

45 McClanahan, "Serious Crises," 121.

${ }^{46}$ Ibid., 127.

${ }^{47}$ Chantal Mouffe, For a Left Populism (London: Verso, 2018); Slavoj Zizek, The Courage of Hopelessness (London: Penguin, 2017). 